\title{
ANALISIS PERBAIKAN TERHADAP TATA LETAK GUDANG PRODUK JADI PT SPM DENGAN MENGGUNAKAN METODE DEDICATED STORAGE
}

\author{
Burhanudin \\ Program Studi Teknik Industri, Fakultas Teknik \\ Universitas Maarif Hasyim Latif, Sidoarjo, Indonesia \\ e-mail : burhanudin@student.umaha.ac.id
}

\begin{abstract}
ABSTRAK
PT. SPM merupakan perusahaan yang memproduksi berbagai jenis tissue dengan skala yang besar. Gudang barang jadi PT. SPM memiliki kapasitas 4171 pallet posisi. Permasalahan pada gudang tersebut adalah belum dibentuknya penempatan produk secara spesifik. Perbaikan tata letak gudang dianalisis dengan metode dedicated storage. Hasil perancangan dengan dedicated storage didapat penurunan jarak material handling sebesar 7,76 meter atau $8 \%$ dari jarak sebelumnya yaitu 40.28 meter dalam satu kali aktivitas dengan penempatan produk pada posisi yang spesifik dan tetap.
\end{abstract}

Kata Kunci : dedicated Storage, gudang, tata letak.

\section{PENDAHULUAN}

Gudang penyimpanan PT. SPM memakai sistem racking dan unracking, akan tetapi dalam penyimpanan produk jadi masih belum terkoordinir dengan baik. Penataan dan penyimpanan antara jenis produk satu dengan produk yang lain masih bercampur sehingga pada pengambilan produk menambah proses hadling bolak-balik yang memperlambat proses pengambilan sehingga sistem FIFO yang tidak berjalan. Jarak rata-rata dalam proses pencarian pada setiap produk dalam bin atau slot ialah 40.28 meter dan waktu pencarian ratarata 3.53 menit dengan kecepatan forklift 11,6 km/jam.

Menurut (Anshori, Fudhla, \& Hidayat, 2017) penentuan lokasi fasilitas pada sebuah gudang menjadi sangat penting, karena akan sangat berpengaruh kepada seberapa pemasok barang dari titik pasokan ke beberapa pedagang retail.

Menurut (Retnowati \& Fudhla, n.d.) suatu perancangan sebuah tata letak yang kurang baik berdampak pada biaya tak terduga dengan jumlah yang cukup besar, diantaranya dari kualitas produk dan moral tenaga kerja yang menurun, hingga responstime perusahaan yang menurun dalam memenuhi permintaan customer.

(Siregar, Sukatendel, \& Tarigan, 2013) Tujuan dari sebuah penelitian terkait tata letak adalah untuk mendapatkan tata letak gudang barang jadi yang memiliki total jarak dan waktu pemindahan yang minimum.

Menurut (Athoillah \& Irawan, 2013) Gudang merupakan satu dari sekian banyak bagian terpenting dari sebuah perusahaan ataupun pabrik yang memiliki fungsi sebagai tempat untuk menyimpan suatu barang baik dari hasil produksi ataupun bahan baku dari supplier. Salah satu metode dalam pengaturan sebuah tata letak gudang agar aktivitas di dalam gudang tersebut dapat terkoordinasi serta penggunaan area penyimpanan di dalam gudang akan menjadi optimal adalah dedicated storage. Menurut (Aliudin, Ilhami, \& Febianti, 2015), dedicated storage merupakan sebuah metode untuk tata letak penyimpanan produk yang berdasar banyaknya aktivitas (throughput) penerimaan dan penjualan produk dengan memperhitungkan jarak handling paling dekat terhadap I/O point. Penerapan dedicated storage dilakukan agar produk yang di simpan dapat menempati lokasi tetap untuk memudahkan pekerja di dalamnya dalam proses penerimaan, penyimpanan serta penjualan, sehingga aliran pada barang atau produk menjadi lancar serta mengoptimalkan kebutuhan pada area atau lokasi (space requirement). Penelitian terkait pernah di lakukan oleh (Abdullah, 2009) di PT. CAKUP pada gudang barang jadi. Metode yang digunakan dedicated storage dengan hasil penghematan ruangan sebesar $45,91 \%$ dari areal yang tersedia.

Mengingat betapa pentingnya suatu tata letak dalam suatu gudang barang jadi, maka dari itu perlu di lakukannya analisis tata letak gudang produk jadi di PT SPM agar menghasilkan layout yang lebih teratur, tertata dan lebih rapi dari layout yang ada sebelumya. Maka dari itu, penulis akan melakukan analisis terhadap tata letak gudang barang jadi PT SPM dengan metode dedicated storage untuk mendapatkan posisi produk yang tetap dan spesifik pada tata letak gudang produk jadi dengan mempertimbangkan tingkat aktivitas produk serta area yang di butuhkan.

Berdasar permasalah yang ada, maka tujuan penelitian ini ialah untuk menempatkan produk berdasarkan tingkat aktivitas dan area yang dibutuhkan. Merancang perbaikan tata letak dengan metode dedicated storage sehingga mendapatkan lokasi yang tetap dan mengurangi jarak tempuh dalam proses handling. 


\section{METODE PENELITIAN}

Ada beberapa tahapan yang harus di lalui agar alur penelitian yang dilakukan dapat terstruktur sesuai dengan tujuan yang akan dicapai. Sangat penting bagi peneliti untuk berpedoman pada beberapa konsep dan teori sebagai landasan sehingga tujuan penelitian dapat tercapai. Studi pendahuluan berupa observasi dan wawancara ke tempat yang akan dilaksanakannya penelitian untuk mendapatkan gambaran awal tentang kondisi aktual perusahaan. Langkah study dalam pendahuluan bertujuan untuk mendapatkan informasi mengenai permasalahan yang akan dilakukanya penelitian serta data-data di dalamnya. Data yang dikumpulkan berdasarkan data yang dimiliki perusahaan. Data yang dapat dikumpulkan berupa luas gudang yang digunakan, kapasitas gudang, data jenis produk, data penerimaan pada tahun 2018, data penjualan pada tahun 2018, MHE (Material Handling Equipment), kapasitas pallet.

Dalam merancang sebuah perbaikan tata letak gudang PT. SPM data yang akan diolah dengan metode dedicated storage. Adapun beberapa tahapan atau langkah-langkah yang digunakan dalam metode Dedicated Storage adalah sebagai berikut:

\section{1. space requirment $(\mathrm{S})$}

Space Requirement merupakan suatu kebutuhan tempat atau lokasi dalam satuan slot, blok atau bin yang mana ditempatkan pada lokasi yang hanya satu jenis produk dan spesifik yang ditempatkan pada area penyimpanan tersebut. Untuk perhitungan kebutuhan ruang $(\mathrm{S})$ adalah:

$$
\begin{aligned}
\mathrm{S} & =\frac{\text { Jumlah penjualan per produk }}{\text { jumlah penjualan keseluruhan produk }} \\
& =\text { kontribusi jual }(\%) \quad x \text { jumiah Slot atau bin (Pallet Posisi) }
\end{aligned}
$$

\section{2. throughput (T)}

Dilakukanya suatu perhitungan aktivitas yang bersifat dinamis, serta menunjukkan suatu aliran dalam sebuah aktivitas di dalam gudang. Pengukuran throughput dilakukan berdasarkan aktivitas penerimaan dan juga penjualan yang terjadi di dalam gudang. Untuk perhitungan throughput antara lain:

$$
\mathrm{T}=\frac{\text { Rata }- \text { rata Penerimaaan }}{\text { Jumlah produk dalam pallet }}+\frac{\text { Rata }- \text { rata pejualan }}{\text { Jumlah produk dalam pallet }}
$$

\section{Penempatan Produk (Assignment)}

Penempatan suatu produk berdasar pada nilai $\mathrm{T} / \mathrm{S}$ terbesar, dengan jarak terdekat dari I/O point. Perhitungan T/S ini dilakukan guna menjadikan sebuah acuan awal pada penempatan sebuah produk. Rumus untuk perhitungan T/S adalah sebagai berikut:

$$
\frac{\mathrm{T}}{\mathrm{S}}=\frac{\text { Throughput }}{\text { Space Requirement }}
$$

Hasil perhitungan $\mathrm{T} / \mathrm{S}$ kemudian diurutkan mulai dari yang terbesar hingga terkecil untuk penempatan produk pada lokasi penyimpanan. Dalam penempatan produk dilakukan berdasar dari nilai T/S yang terbesar hingga terkecil.

Analisis hasil dengan membandingkan jarak dan waktu antara tata letak gudang aktual dengan tata letak gudang usulan yang menggunakan metode dedicated storage. Kemudian hasil dari penelitian dapat disimpulkan yang merupakan jawaban dari tujuan penelitian.

\section{HASIL DAN PEMBAHASAN}

\section{Data Kategori Produk}

Hasil produksi di PT. SPM sebelum didistribusikan terlebih dahulu disimpan pada gudang produk jadi dalam bentuk box dalam sebuah tatanan pallet. Jenis produk yang disimpan dalam gudang produk jadi PT. SPM beserta jumlah kode produk dalam tiap kategori dan jumlah box dalam satuan pallet, yang dijelaskan pada Tabel 1.

Tabel 1. Produk Yang Disimpan Dalam Gudang

\begin{tabular}{ccc}
\hline Kategori & $\begin{array}{c}\text { Jumlah } \\
\text { Kode } \\
\text { Produk }\end{array}$ & $\begin{array}{c}\text { jumlah satuan } \\
\text { per pallet } \\
\text { (box) }\end{array}$ \\
\hline Bathroom Tissue & 71 & 24 \\
\hline $\begin{array}{c}\text { Hand towel } \\
\text { Multifold }\end{array}$ & 7 & 56 \\
\hline Facial Tissue & 57 & 24 \\
\hline Coctail Napkin & 82 & 45 \\
\hline $\begin{array}{c}\text { Bathroom } \\
\text { Multipurpose }\end{array}$ & 1 & 70 \\
\hline kitchen towell & 6 & 56 \\
\hline Luncheon Napkin & 11 & 42 \\
\hline Dinner Napkin & 31 & 56 \\
\hline Clinical Roll Towel & 2 & 27 \\
\hline FacialMultipurpose \\
Tisuue
\end{tabular}

2. Data Penerimaan Dan Penjualan

Data yang diperoleh adalah data penerimaan dari produksi dan juga penjualan mulai bulan Januari hingga Desember 2018. Data penerimaan dan penjualan pada bulan Januari dapat dilihat pada Tabel 2 .

Tabel 2. Data Penerimaan Dan Penjualan Produk

\begin{tabular}{ccc}
\hline Produk & Penerimaan & Penjualan \\
\hline Bathroom Tissue & 296086 & 287662 \\
\hline Facial Tissue & 142312 & 137784 \\
\hline Dinner Napkin & 37260 & 35948 \\
\hline Clinical Roll Towel & 3403 & 3328 \\
\hline Luncheon Napkin & 42853 & 41354 \\
\hline Coctail Napkin & 102988 & 100440 \\
\hline Hand Towel Multifold & 537312 & 525629 \\
\hline Kitchen Towell & 74877 & 73248
\end{tabular}




\begin{tabular}{ccc}
\hline Produk & Penerimaan & Penjualan \\
\hline $\begin{array}{c}\text { Facialmultipurpose } \\
\text { Tisuue }\end{array}$ & 6519 & 5122 \\
\hline $\begin{array}{c}\text { Bathroom } \\
\text { Multipurpose }\end{array}$ & 104572 & 102021 \\
\hline Handkerchief & 5204 & 5091
\end{tabular}

3. Rata-Rata Penerimaan dan penjualan

Data rata-rata penerimaan dan penjuaalan merupakan data dari jumlah produk yang masuk ataupuan keluar gudang dan di rata-rata dengan asumsi 1 tahun atau 12 bulan. Data rata-rata penerimaan dan penjualan dapat di lihat pada Tabel 3.

Tabel 3. Data Rata-Rata Penerimaan Dan Penjualan

\begin{tabular}{ccc}
\hline Kategori & $\begin{array}{c}\text { Rata-rata } \\
\text { Penerimaan }\end{array}$ & $\begin{array}{c}\text { Rata-rata } \\
\text { Penjualan }\end{array}$ \\
\hline Bathroom Tissue & 148469 & 144257 \\
\hline $\begin{array}{c}\text { Hand towel } \\
\text { Multifold }\end{array}$ & 268698 & 262857 \\
\hline Facial Tissue & 71498 & 69234 \\
\hline Coctail Napkin & 51986 & 50712 \\
\hline $\begin{array}{c}\text { Bathroom } \\
\text { Multipurpose }\end{array}$ & 52292 & 51017 \\
\hline kitchen towell & 37475 & 36660 \\
\hline Luncheon Napkin & 21493 & 20743 \\
\hline Dinner Napkin & 18816 & 18160 \\
\hline Clinical Roll Towel & 1714 & 1676 \\
\hline $\begin{array}{c}\text { FacialMultipurpose } \\
\text { Tisuue }\end{array}$ & 3283 & 2585 \\
\hline Handkerchief & 2608 & 2552 \\
\hline
\end{tabular}

4. Tata Letak Awal Gudang Produk Jadi PT. SPM

Lokasi penyimpanan pada gudang produk jadi

PT. SPM digambarkan dalam sebuah bentuk template agar memudahkan pembaca dalam memahami, gudang produk jadi PT. SPM memiliki kapasitas penyimpanan yaitu sejumlah 4.171 pallet posisi. Layout penyimpanan produk pada gudang PT. SPM dapat dilihat pada Gambar 4.

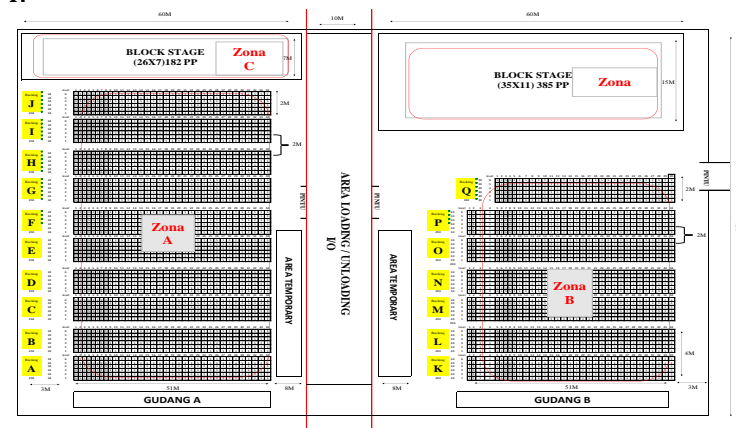

Gambar 4. Layout awal Gudang Produk Jadi PT. SPM

PT. SPM memiliki 2 gudang produk jadi yang masing-masing memiliki luas yang sama, yaitu gudang $\mathrm{A}$ dan gudang B. Gudang produk jadi PT. SPM memiliki luas $\pm 4800 \mathrm{~m} 2$ yang terbagi menjadi 4 bagian zona, yaitu zona A, B, C, dan D. Zona A dan Zona B merupakan racking area dan Zona C dan D merupakan unracking atau blockstage area. Susunan produk yang ada di gudang saat ini tidak teratur karena tidak ada penempatan produk yang spesifik tempat spesifik untuk menyimpan produk. Dalam penyimpanan, produk yang masuk hanya disimpan pada slot atau bin yang kosong dan apabila slot atau bin tersebut masih terisi maka tidak boleh ada penyimpanan pada slot atau bin tersebut. Kapasitas slot penyimpanan dari tiap zona dapat di lihat pada Tabel 4.

Tabel 4. Kapasitas slot atau bin Penyimpanan Tiap Zona

\begin{tabular}{ccc}
\hline Zona & Blok/Rak & $\begin{array}{c}\text { Kapasitas Slot } \\
\text { (Pallet Posisi) }\end{array}$ \\
\hline & A1-A34 & 204 \\
\cline { 2 - 3 } & B1-B34 & 204 \\
\cline { 2 - 3 } & C1-C34 & 204 \\
\cline { 2 - 3 } A & D1-D34 & 204 \\
\cline { 2 - 3 } & E1-E34 & 204 \\
\cline { 2 - 3 } & F1-F34 & 204 \\
\cline { 2 - 3 } & G1-G34 & 204 \\
\cline { 2 - 3 } & H1-H34 & 204 \\
\cline { 2 - 3 } & I1-I34 & 204 \\
\cline { 2 - 3 } & J1-J34 & 204 \\
\cline { 2 - 3 } & K1-K34 & 204 \\
\cline { 2 - 3 } & L1-L34 & 204 \\
\cline { 2 - 3 } B & M1-M34 & 204 \\
\cline { 2 - 3 } & N1-N34 & 204 \\
\cline { 2 - 3 } & O1-034 & 204 \\
\cline { 2 - 3 } & P1-P34 & 204 \\
\cline { 2 - 3 } & Q1-Q3 & 180 \\
\hline C & Blok 1-31 & 182 \\
\hline D & Blok 1-35 & 510 \\
\hline & TOTAL & 4171
\end{tabular}

\section{PENGOLAHAN DATA}

Data-data yang diperoleh di atas kemudian diolah untuk mendapatkan penyelesaian dalam sebuah persoalan tata letak gudang terutama dalam penentuan lokasi penyimpan barang di gudang. Persoalan ini diselesaikan guna mendapatkan sebuah lokasi penyimpanan barang yang tepat sehingga mengurangi jarak dan waktu dalam proses pengambilan barang. Metode yang digunakan dalam penelitian ini ialah dedicated storage yang mana produk yang disimpan ditempatkan pada lokasi yang tetap dan hanya dengan satu jenis produk yang pada lokasi tersebut. Adapun tahapan metode dedicated storage adalah sebagai berikut:

1. Space Requirement (Kebutuhan Ruang)

Tahapan yang pertama yaitu penentuan kebutuhan ruang bertujuan untuk menentukan kapasitas slot atau bin untuk menyimpan produk sesuai dengan kategori dan kode produk. Contoh perhitungan kebutuhan slot atau bin untuk kategori produk Bathroom Tissue dengan jumlah penjualan sebesar 287.662 box. Dalam penjualan keseluruhan kategori 
produk sebesar 1.317.627 box dan dengan kontribusi jual sebesar $22 \%$, dengan kapasitas penyimpanan 4171 pallet posisi berikut adalah perhitungan space requirement untuk kategori produk Bathroom Tissue :

$$
S=\frac{287.662}{1.317 .627} \times 4171=912 \text { pallet posisi }
$$

Seperti yang sudah dijelaskan, kapasitas slot atau bin pada gudang berbeda-beda. Kebutuhan ruang untuk tiap jenis produk dapat dilihat pada Tabel 5.

Tabel 5. Kebutuhan Ruang Tiap Produk

\begin{tabular}{ccc}
\hline Kategori & $\begin{array}{c}\text { Jumlah } \\
\text { Satuan } \\
\text { Perpallet } \\
\text { (Box) }\end{array}$ & $\begin{array}{c}\text { Kebutuhan } \\
\text { Ruang } \\
\text { (Slot/Blok) }\end{array}$ \\
\hline Hand Towel Multifold & 56 & 1603 \\
\hline Bathroom Tissue & 24 & 912 \\
\hline Facial Tissue & 24 & 451 \\
\hline Coctail Napkin & 45 & 357 \\
\hline Bathroom Multipurpose & 70 & 311 \\
\hline Kitchen Towell & 56 & 226 \\
\hline Dinner Napkin & 56 & 132 \\
\hline Luncheon Napkin & 42 & 131 \\
\hline Facialmultipurpose & 70 & 17 \\
\hline Tisuue & 70 & 16 \\
\hline Handkerchief & 27 & 11 \\
\hline Clinical Roll Towel & &
\end{tabular}

Berdasarkan Tabel 5 di atas dapat ketahui bahwa kebutuhan ruang utuk produk tertinggi ialah produk Hand Towel Multifold yaitu dengan kebutuhan pallet 1603 pallet. Produk dengan kebutuhan slot atau ruang yang paling rendah ialah Clinical Roll Towel dengan kebutuhan 11 pallet.

\section{Perhitungan Throughput}

Throughput merupakan sebuah ukuran jumlah aktivitas penerimaan dan pengeluaran produk yang terjadi dalam periode waktu. Aktivitas penerimaan dan pengeluaran di gudang menggunakan material handling berupa forklift. Dalam sekali pengangkut dengan MHE (Material Handling Equipment) dapat memindahkan 1 pallet yang di atasnya berisi tatanan produk. Maka aktivitas penerimaan dan pengeluaran produk dikonversikan ke dalam satuan pallet. Contoh perhitungan throughput untuk kategori produk Bathroom Tissue dengan rata-rata jumlah penerimaan sebesar 148.469 box. Dalam rata-rata jumlah penjualan sebesar 144.257 box dan dengan jumlah box per pallet ialah 24 box, maka throughput untuk kategori produk Bathroom Tissue adalah :

$$
\mathrm{T}=\frac{148.469 \text { box }}{24 \text { box }}+\frac{144.257 \text { box }}{24 \text { box }}=12.197 \text { Aktivitas }
$$

Hasil perhitungan throughput untuk masingmasing produk dapat dilihat pada Tabel 6.
Tabel 6 Perhitungan Throughput Untuk tiap

\begin{tabular}{|c|c|c|c|c|}
\hline Kategori & $\begin{array}{c}\text { jumlah } \\
\text { satuan } \\
\text { perpal } \\
\text { et } \\
\text { (box) }\end{array}$ & $\begin{array}{l}\text { Rata- } \\
\text { rata } \\
\text { Peneri } \\
\text { maan }\end{array}$ & $\begin{array}{l}\text { Rata- } \\
\text { rata } \\
\text { Penjua } \\
\text { lan }\end{array}$ & $\begin{array}{c}\text { Throug } \\
\text { hput }\end{array}$ \\
\hline $\begin{array}{c}\text { Bathroom } \\
\text { Tissue }\end{array}$ & 24 & $\begin{array}{c}14846 \\
9 \\
\end{array}$ & $\begin{array}{c}14425 \\
7 \\
\end{array}$ & 12197 \\
\hline $\begin{array}{c}\text { Hand towel } \\
\text { Multifold }\end{array}$ & 56 & $\begin{array}{c}26869 \\
8 \\
\end{array}$ & $\begin{array}{c}26285 \\
7 \\
\end{array}$ & 9492 \\
\hline Facial Tissue & 24 & 71498 & 69234 & 5864 \\
\hline $\begin{array}{l}\text { Coctail } \\
\text { Napkin }\end{array}$ & 45 & 51986 & 50712 & 2282 \\
\hline $\begin{array}{c}\text { Bathroom } \\
\text { Multipurpose }\end{array}$ & 70 & 52292 & 51017 & 1476 \\
\hline kitchen towel & 56 & 37475 & 36660 & 1324 \\
\hline $\begin{array}{l}\text { Luncheon } \\
\text { Napkin }\end{array}$ & 42 & 21493 & 20743 & 1006 \\
\hline $\begin{array}{l}\text { Dinner } \\
\text { Napkin }\end{array}$ & 56 & 18816 & 18160 & 660 \\
\hline $\begin{array}{c}\text { Clinical Roll } \\
\text { Towel }\end{array}$ & 27 & 1714 & 1676 & 126 \\
\hline $\begin{array}{l}\text { FacialMultipu } \\
\text { rpose Tisuue }\end{array}$ & 70 & 3283 & 2585 & 84 \\
\hline Handkerchief & 70 & 2608 & 2552 & 74 \\
\hline
\end{tabular}

Produk

Dari hasil perhitungan throughput dari tiap produk, maka dapat di lihat bahwa produk Bathroom Tissue memiliki aktivitas tertinggi yaitu sebesar 12.197 aktivitas. Dan untuk aktivitas terendah ialah produk Handkerchief sebanyak 74 aktivitas.

3. Penempatan Produk (Assignment)

Penempatan produk dilakukan dengan menghitung perbandingan Throughput dan juga Space requirement $(\mathrm{T} / \mathrm{S})$ dari tiap jenis produk. Perhitungan $\mathrm{T} / \mathrm{S}$ ini digunakan untuk dijadikan acuan pada penempatan produk. T/S paling besar ditempatkan pada slot atau bin yang terdekat dengan area loading dan unloading. Berikut contoh perhitungan T/S untuk kategori produk Bathroom Tissue dengan throughput 12.197 aktivitas. dan Space Requirement 912 pallet posisi :

$$
\frac{\mathrm{T}}{\mathrm{S}}=\frac{12197.08}{912}=13.37
$$

Setelah perbandingan Throughput dengan Space requirement $(\mathrm{T} / \mathrm{S}$ ) didapat maka di ranking nilai $\mathrm{T} / \mathrm{S}$ tiap produk dari urutan paling hingga terkecil. Nilai T/S setiap produk yang telah diurutkan dapat dilihat pada Tabel 7.

Tabel 7. Perankingan T/S Tiap Produk

\begin{tabular}{cc}
\hline Produk & T/S \\
\hline Bathroom Tissue & 13.37 \\
\hline Facial Tissue & 13.00 \\
\hline Dinner Napkin & 11.67 \\
\hline
\end{tabular}




\begin{tabular}{cc}
\hline Produk & T/S \\
\hline Clinical Roll Towel & 11.41 \\
\hline Luncheon Napkin & 7.68 \\
\hline Coctail Napkin & 6.39 \\
\hline Hand Towel Multifold & 5.92 \\
\hline Kitchen Towell & 5.86 \\
\hline Bacialmultipurpose Tisuue & 4.93 \\
\hline Handkerchief & 4.75 \\
\hline
\end{tabular}

Rekapan data terkait perankingan $\mathrm{T} / \mathrm{S}$ tiap kategori dapat di lihat dengan jumlah nilai T/S terbesar, yaitu Bathroom Tissue dengan total nilai T/S sebesar 13.37. Sedangkan untuk nilai $\mathrm{T} / \mathrm{S}$ terkecil ialah Handkerchief sebesar 4.61. Di dalam tiap kategori produk memiliki klasifikasi penjualan masing-masing yang di bagi menjadi 3 klasifikasi yaitu kategori A : Fast Moving, B : Slow Moving dan C : Medium Moving. Data klasifikasi dari tiap kategori produk dapat dilihat pada Tabel 8.

Tabel 8. Klasifikasi Dari Tiap Kategori Produk

\begin{tabular}{cc}
\hline Klasifikasi Produk & $\begin{array}{c}\text { Jumlah Kode } \\
\text { Produk }\end{array}$ \\
\hline A & 23 \\
\hline B & 44 \\
\hline C & 206 \\
\hline Grand Total & 273 \\
\hline
\end{tabular}

Setalah nilai $\mathrm{T} / \mathrm{S}$ masing-masing produk diurutkan dan didapatkannya klasifikasi dari tiap kategori produk maka dapat disusun penempatan masing-masing produk di dalam gudang. Gambar tata letak gudang usulan gudang produk jadi PT. SPM digambarkan dalam sebuah bentuk template dapat di lihat pada Gambar 4.

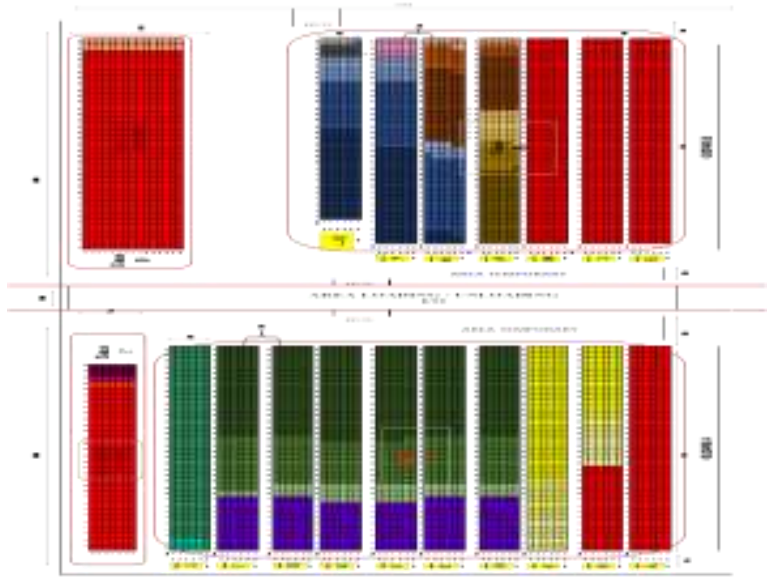

Gambar 4. Tata Letak Gudang Usulan gudang produk jadi PT. SPM

Keterangan :

\begin{tabular}{l|ccc} 
Bathroom Tissue & A & B & C \\
Facial Tissue & A & B & C
\end{tabular}

\section{Coctail Napkin \\ Dinner Napkin \\ Luncheon Napkin \\ Hand towel Multifold \\ kitchen towel \\ A $\quad$ B $\quad$ C \\ A $\quad$ B $\quad$ C \\ A B C \\ A $\quad$ B $\quad$ C \\ A B \\ A B \\ Clinical Roll Towel

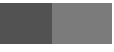 \\ FacialMultipurpose A B \\ Tisuue

$\begin{array}{cc}\begin{array}{c}\text { Bathroom } \\ \text { Multipurpose }\end{array} & \mathrm{A} \\ & \\ \text { Handkerchief } & \mathrm{B}\end{array}$

Berdasarkan tata letak gudang usulan yang sudah di buat, dapat di lihat pada Gambar 4, bahwa sudah terbagi penempatan yang tetap untuk semua kategori produk yang sudah dibedakan dengan warna dan juga telah di susun menurut tingkat aktivitas pada kategori produk tersebut guna memudahkan pengambilan produk secara FIFO.

Penempatan produk dilakukan dengan cara menempatkan produk dengan nilai $\mathrm{T} / \mathrm{S}$ tertinggi pada blok yang dekat dengan area bongkar muat. Pada metode ini setiap jenis produk harus memiliki tempat yang tetap dan penempatan produk pada slot atau bin hanya untuk produk yang sama kategorinya. Hasil penempatan produk pada setiap blok dapat dilihat pada Tabel 9.

Tabel 9. Penempatan Produk

\begin{tabular}{cc}
\hline Produk & Slot/Blok \\
\hline \multirow{3}{*}{ Bathroom Tissue } & $\mathrm{D} 1-\mathrm{D} 25$ \\
\cline { 2 - 2 } & $\mathrm{E} 1-\mathrm{E} 25$ \\
\cline { 2 - 2 } & $\mathrm{F} 1-\mathrm{G} 25$ \\
\cline { 2 - 2 } Facial Tissue & $\mathrm{H} 1-\mathrm{G} 25$ \\
& $\mathrm{I} 1-\mathrm{H} 25$ \\
\cline { 2 - 2 } Coctail Napkin & $\mathrm{O} 1-\mathrm{P} 1-\mathrm{P} 27$ \\
\hline \multirow{2}{*}{ Dinner Napkin } & $\mathrm{B} 1-\mathrm{Q} 27$ \\
\hline \multirow{2}{*}{ Luncheon Napkin } & $\mathrm{C} 1-\mathrm{C} 34$ \\
\hline Hand Towel Multifold & $\mathrm{N} 1-\mathrm{N} 22$ \\
\hline & $\mathrm{O} 23-34$ \\
\hline
\end{tabular}




\begin{tabular}{|c|c|}
\hline Produk & Slot/Blok \\
\hline & B21-B34 \\
\hline & K1-K34 \\
\hline & L1-L34 \\
\hline & M1-M34 \\
\hline & Blok B 1-35 \\
\hline & Blok A 4-31 \\
\hline Kitchen Towell & J1-J34 \\
\hline Clinical Roll Towel & Q28-Q30 \\
\hline $\begin{array}{c}\text { Facialmultipurpose } \\
\text { Tisuue }\end{array}$ & Blok A 1-3 \\
\hline \multirow{6}{*}{$\begin{array}{c}\text { Bathroom } \\
\text { Multipurpose }\end{array}$} & D27-D34 \\
\hline & E27-E34 \\
\hline & F27-F34 \\
\hline & G27-G34 \\
\hline & H27-H34 \\
\hline & I27-I34 \\
\hline Handkerchief & P32-P34 \\
\hline
\end{tabular}

Berdasarkan Tabel diatas, maka dapat dilihat bahwa T/S terbesar adalah produk Bathroom Tissue dengan nila T/S 13.37, ini menunjukkan aktivitas produk tersebut fast moving. Maka sebab itu, produk Bathroom Tissue ditempatkan pada tempat yang paling dekat dengan area bongkar muat I/O yaitu D1-D25, E1E25, F1-F25, G1-G25, H1-H25 dan I1-I25. Sedangkan untuk nilai T/S paling rendah ialah produk Handkerchief dengan nilai $\mathrm{T} / \mathrm{S}$ sebesar 4,6. Oleh sebab itu, produk ini ditempatkan jauh dari area bongkar muat I/O yaitu pada P32-P34. Berdasarkan tata letak gudang usulan yang dibuat, maka dapat dilihat bahwa sudah terdapat pembagian yang tetap untuk tiap kategori produk yang telah dibedakan sehingga memudahkan pekerja dalam pengambilan produk secara FIFO.

\section{Perbandingan Waktu Pencarian Aktual dan Usulan}

Perhitungan waktu aktual dan usulan dilakukan sebagai parameter untuk mengetahui apakah layout usulan lebih baik dibandingkan dengan tata letak gudang aktual. Berdasarkan pengamatan rata-rata waktu pengambilan produk dalam satu kali aktivitas adalah 3.53 menit dan dengan jarak tempuh lokasi penyimpanan dengan area bongkar muat I/O rata-rata 40.28 meter dengan kecepatan rata-rata $11.6 \mathrm{~km} / \mathrm{jam}$. Sebagai perbandingan maka perlu adanya perhitungan waktu pencarian produk pada layout usulan agar dapat dilihat perbandingan pada waktu aktual dan waktu pada tata letak gudang usulan. Setelah tata letak gudang usulan dibuat maka dapat dihitung waktu pengambilan produk pada tata letak gudang usulan dengan mengonversikan jarak tempuh ke waktu. Dengan asumsi kecepatan forklift $11.6 \mathrm{~km} / \mathrm{jam}$. Jarak tempuh setiap slot atau bin diukur dengan menggunakan metode aisle. Hasil perhitungan waktu pencarian pada tata letak gudang usulan dapat dilihat pada Tabel 10 .

Tabel 10 . Perhitungan Waktu Pencarian Pada Tata Letak Gudang Usulan

\begin{tabular}{cccc}
\hline Produk & $\begin{array}{c}\text { Rata- } \\
\text { Rata } \\
\text { Jarak } \\
\text { I/O }\end{array}$ & Kecepatan & Waktu \\
\hline Bathroom Tissue & 2.8 & 11.6 & 2.4 \\
\hline Facial Tissue & 29.0 & 11.6 & 2.5 \\
\hline Coctail Napkin & 38.3 & 11.6 & 3.3 \\
\hline Dinner Napkin & 26.5 & 11.6 & 2.3 \\
\hline Luncheon Napkin & 49.8 & 11.6 & 4.3 \\
\hline $\begin{array}{c}\text { Hand Towel } \\
\text { Multifold }\end{array}$ & 42.4 & 11.6 & 3.7 \\
\hline Kitchen Towell & 39.2 & 11.6 & 3.4 \\
\hline Clinical Roll Towel & 27.0 & 11.6 & 2.3 \\
\hline $\begin{array}{c}\text { Facialmultipurpose } \\
\text { Tisuue }\end{array}$ & 9.8 & 11.6 & 0.8 \\
\hline $\begin{array}{c}\text { Bathroom } \\
\text { Multipurpose }\end{array}$ & 49.0 & 11.6 & 4.2 \\
\hline Handkerchief & 44.0 & 11.6 & 3.8 \\
\hline $\begin{array}{c}\text { Rata-rata } \\
\text { pengambilan } \\
\text { produk }\end{array}$ & 32.5 & & 3.0 \\
\hline
\end{tabular}

Dari Tabel 10 dapat dilihat bahwa waktu pencarian usulan terhadap produk ialah 3.0 menit dan dengan jarak tempuh 32.5 meter. Maka dapat di lihat pengurangan waktu dan jarak pada Table 11 berikut:

Tabel 11. perbandigan waktu dan jarak pada tata letak gudang aktual dan usulan.

\begin{tabular}{|c|c|c|c|}
\hline Perbandingan & $\begin{array}{c}\text { Rata- } \\
\text { Rata } \\
\text { Jarak } \\
\text { I/O }\end{array}$ & Kecepatan & Waktu \\
\hline Aktual & 40.28 & \multirow{3}{*}{11.6} & 3.53 \\
\hline Perbaikan & 32.52 & & 3 \\
\hline Selisih & 7.76 & & 0.53 \\
\hline
\end{tabular}

Dari tabel di atas di ketahui selisih rata-rata dari jarak rak atau blok menuju I/O bongkar muat aktual dengan perbaikan adalah berkurang sebesar 4.78 meter dan dengan selisih waktu rata-rata berkurang sebesar 0.52 menit atau sama dengan $8 \%$.

\section{KESIMPULAN}

Dari hasil pembahasan dengan penerapan metode dedicated storage, kebutuhan ruang untuk tiap produk yang ada di gudang tertinggi ialah kategori produk Hand Towel Multifold sebanyak 1603 pallet. Produk dengan kebutuhan ruang terendah ialah Clinical Roll Towel dengan kebutuhan ruang 11 pallet. Throughput dari tiap produk yang telah dihitung yang mana kategori produk Bathroom Tissue memiliki nilai aktivitas tertinggi yaitu 12.197 aktivitas. Sedangkan kategori produk Handkerchief memiliki jumlah aktivitas terkecil yaitu sebanyak 74 aktivitas.

Dalam penyusunan Layout usulan tahapan yang di lalui ialah perankingan nilai $\mathrm{T} / \mathrm{S}$ yaitu dengan 
memperbandingkan jumlah Throughput dengan jumlah Space requirement. Didapatkan penempatan kategori produk yang setiap kategori produk menempati tempat yang tetap, sesuai dengan kebutuhan ruang dan tingkat aktivitas sehingga memudahkan pekerja dalam pengambilan produk secara FIFO. Dari perankingan T/S di dapat nilai $\mathrm{T} / \mathrm{S}$ terbesar ialah kategori produk Bathroom Tissue dengan nilai 13.37 sehingga kategori produk tersebut ditempatkan lebih dekat dengan area bongkar muat I/O. Terjadi penurunan total jarak material handling yangvmana pada kondisi aktual total jarak material handling sebesar 40.28 meter dengan waktu pengambilan sebesar 3.53 menit dengan kecepatan MHE $11.6 \mathrm{Km} / \mathrm{jam}$, sedangkan pada layout usulan menjadi sebesar 32.53 meter. Artinya terjadilah penurunan total jarak material handling sebesar 7.76 meter atau sekitar 8\%, dengan waktu pengambilan sebesar 3.00 menit dari kondisi awal. Angka ini menunjukan jarak total perjalanan yang dibutuhkan material handling di dalam gudang barang jadi PT. SPM dalam satu kali aktivitas pengambilan pada seluruh produk yang ada di dalam gudang.

\section{DAFTAR PUSTAKA}

Abdullah, F. (2009). Usulan Perbaikan Tata Letak Gudang Produk Jadi Dengan Menggunakan Metode Dedicated Storage Di PT. Cahaya Kawi Ultra Polyintraco.
Aliudin, T. M. A., Ilhami, M. A., \& Febianti, E. (2015). Usulan Perbaikan Tata Letak Gudang Produk Drum Oli Menggunakan Metode Dedicated Storage Di PT XYZ. Jurnal Teknik Industri Untirta, 3(1).

Anshori, M., Fudhla, A. F., \& Hidayat, A. (2017). Penentuan Lokasi Fasilitas Crossdock pada Kota Metropolis dengan Pendekatan Center Of Gravity. Teknika: Engineering and Sains Journal, 1(2), 83-88.

Athoillah, M., \& Irawan, M. I. (2013). Perancangan sistem informasi mobile berbasis Android untuk kontrol persediaan barang di gudang. Jurnal Sains Dan Seni Pomits, 1(1), 1-6.

Retnowati, D., \& Fudhla, A. F. (n.d.). RE-LAYOUT FASILITAS PRODUKSI INDUSTRI SHEET METAL WORKING BERBASIS JOB SHOP DENGAN PENDEKATAN LINEAR MIX INTEGER PROGRAMMING.

Siregar, R. M., Sukatendel, D., \& Tarigan, U. (2013). Perancangan Ulang Tataletak Fasilitas Produksi Dengan Menerapkan Algoritma Blocplan Dan Algoritma Corelap Pada PT. Xyz. Jurnal Teknik Industri USU, 1(1). 